\title{
Ageing and the Conflict of Interest Between Generations
}

\author{
Leon Bettendorf • A. van der Horst • N. Draper • \\ C. van Ewijk • R. de Mooij • H. ter Rele
}

Published online: 27 January 2011

(C) The Author(s) 2011. This article is published with open access at Springerlink.com

\begin{abstract}
The ageing of the population imposes a considerable burden on longterm public finances in most industrialized countries. Generational accounting has been used across the world to assess the generational imbalance associated with current public policies. In this study, we incorporate Dutch generational accounts in an open economy overlapping generations model to assess the sustainability gap in current Dutch public finances. Our central estimate of the gap is $4.5 \%$ of gdp, but the paper also shows the sensitivity of this result. We explore a variety of policy reforms to reduce the sustainability gap, thereby presenting the impact on the intergenerational distribution of the net benefit from government.
\end{abstract}

Keywords Ageing · Fiscal sustainability · Public finances ·

Intergenerational distribution

L. Bettendorf $(\varangle) \cdot$ A. van der Horst · N. Draper · C. van Ewijk · R. de Mooij · H. ter Rele CPB Netherlands Bureau for Economic Policy Analysis, P.O. Box 80510, 2508 GM,

The Hague, The Netherlands

e-mail: ljhb@cpb.nl
A. van der Horst
e-mail: avdh@cpb.nl
N. Draper
e-mail: dagd@cpb.nl
C. van Ewijk
e-mail: C.van.Ewijk@cpb.nl
R. de Mooij
e-mail: radm@cpb.nl
H. ter Rele
e-mail: hjmtr@cpb.nl 


\section{JEL Classification $\quad \mathrm{H} 62 \cdot \mathrm{J} 11$}

\section{Introduction}

Generational accounting (GA) studies, as developed by Auerbach et al. (1991), have been widely used to assess the generational imbalance associated with current public policies. During the 1990s, these studies have received a growing attention in several countries (see Auerbach et al. 1999). In particular, they revealed that policies are typically not financially sustainable in the long run, primarily due to the ageing of populations. Therefore, they impose a severe burden on future generations. Indeed, future cohorts would face dramatic increases in their net lifetime tax burden as compared to current generations if policies were not reformed drastically.

The studies from the 1990s received substantial criticism from academics. For instance, Haveman (1994) and Buiter (1995) argued that the accounting framework abstracts from economic behaviour on the part of economic agents. Thus, they may give false indications of the incidence of taxation and are ill suited to simulate the effects of policy reforms. Secondly, the generational imbalance as an indicator for the degree of fiscal unsustainability was criticized, as it puts the entire burden of public debt upon unborn, future generations. Finally, they criticize the computation of the net lifetime tax burden, e.g. due to the use of one uniform social discount rate.

In response to the first criticism, we incorporate the Dutch generational accounts into an overlapping generations model (see also Fehr and Kotlikoff (1996) and Kotlikoff (2002)) with the main aim of capturing the incidence effects of policy reforms. Key elements in this model are endogenous labour supply and endogenous consumption and savings. Secondly, our measure of imbalance, the sustainability gap, indicates the size of the fiscal adjustment needed to guarantee current public expenditure and tax ratios in the long run. It does, however, not assume that only future generations bear this burden. Finally, we meet the third criticism by showing the sensitivity of the sustainability gap to alternative discount rates. The inclusion of multiple rates of return would require a stochastic model, which would only be possible by reducing the size of the model in terms of its institutional detail and the number of generations. ${ }^{1}$

In this study, we present the outcomes from a generational accounting analysis for the Netherlands. We compute the sustainability gap for the Netherlands and explore the impact of policy reforms. The Netherlands has a number of features that differ from most other countries. First, Dutch public finances benefit from a substantial amount of natural gas revenues. This stock will be depleted during the coming decades. Second, the Dutch welfare state finances a relatively large share of expenditures on long-term care, with limited private contributions. Third, the Netherlands has a relatively large funded pension system. The first pillar is financed on a pay-as-you-go basis and provides a minimum income level for pensioners. The second pillar is capital funded and

\footnotetext{
1 See Draper and Westerhout (2010) for a stochastic OLG-model with equity risk and a detailed pension system, which might be a first step in this direction. Extensions to multiple risk factors and detailed modeling of the government budget would be needed for the assessment of the sustainability of public finance in the Netherlands.
} 
is based on a defined benefit scheme. Ageing has a distinct impact on the public budget via these components of the pension system.

The calculations in this study suggest that, if the government would maintain its current gdp-share of revenues and expenditures in the future, the implicit debt included in future primary deficits equals about $300 \%$ of gdp, more than four times the current debt ratio of $65 \%$ of gdp. This amounts to an annual sustainability gap of about $4.5 \%$ of gdp, which indicates that sooner or later a sizable adjustment in either the collective expenditures or tax revenues is needed. The main reasons behind this sustainability gap are the growing expenditures on health care and public pensions in the ageing society and the depletion of the gas resources.

The main conclusion that growing expenditures and declining gas revenues create unsustainable future deficits is robust to alternative assumptions on key parameters, like the discount rate and the growth rate. However, alternative assumptions on public expenditures and revenues might solve the sustainability problem or double it. For example, would one follow the current law where the brackets in the labour income tax are indexed with inflation, future tax burden and revenues would strongly increase and seriously reduce the sustainability gap. On the other hand, would one project that the rising share of health care expenditures continues, the gap becomes much larger.

The sustainability gap implies that policy reform is required to meet the intertemporal government budget constraint. We investigate three types of reforms, cutting expenditures, raising taxes and reforming public pensions. For each reform, we show the impact for the net benefit that different generations receive from the government. This innovative form of presentation offers a good reflection of the intergenerational effects of policy reforms.

The rest of this paper is organized as follows. Section 2 demonstrates our methodological framework of generational accounting in the overlapping generations model. Section 3 presents an application to the Netherlands, thereby assessing the long-term implications for public finances. It computes the sustainability gap associated with these future developments and it performs a sensitivity analysis on the sustainability gap. Section 4 demonstrates the impact of policy reforms. Finally, Sect. 5 concludes.

\section{Generational Accounting in General Equilibrium}

To explore long-term trends in Dutch public finances, this study adopts an overlapping generations model Gamma. The core of the model is a generational accounting (GA) framework, where the benefits and burdens of public finances are assigned to cohorts. There are 100 different cohorts, each represented by an individual with the average characteristics for that age. The government sector is modelled in detail, whereby publicly provided private benefits and taxes are attributed to the different generations distinguished by the model. Government behaviour is assumed to be exogenous and households take public expenditures and the tax system as given. To include economic responses to changes in fiscal policy, Gamma is enriched with choices of firms and households based on optimizing behaviour. The model thus reveals the outcomes for 
employment, consumption and saving. ${ }^{2}$ This section discusses in more detail how the model is structured.

\subsection{Generational Accounting}

Generational accounting is a system that assigns the benefit and burden of public policies to different generations. The construction of the accounts builds on the concept of net benefit from government. Broadly speaking, this net benefit $(N B)$ is computed as follows: ${ }^{3}$

$$
N B_{t}=-B S_{t}-\left(R_{t}-F_{t}\right)+G_{t}-\left(I_{t}-Z_{t}\right), \quad B S_{t}=P S_{t}+R_{t}
$$

where $B S=$ budgetary surplus, $G=$ revenue from natural gas, $R=$ interest payments by government, $F$ = income from financial assets owned by government, $I=$ public investment, $Z=$ imputed benefits from public capital and $P S=$ primary surplus. The calculation in (1) starts with the public deficit, which is equal to total expenditure minus total revenue $(-B S)$. Then, there are two corrections. First, some public expenditures or revenues do not involve a benefit or burden to the private sector, e.g. if there is an exchange with government. Indeed, if you pay for the private provision of a public service, this is a 'normal' economic transaction and the service cannot be classified as a net benefit. Thus, interest payments are not counted as a benefit to households since they form remuneration for savings. Accordingly, interest payments $(R)$ and revenues from financial assets $(F)$ are not included in the concept of net benefit from government in (1). ${ }^{4}$ Second, revenues from natural gas $(G)$ are a source of income for the government that does not form a tax burden to households because the households receive a gas delivery in exchange. Hence, this correction requires that revenues from gas are not counted as a burden and is therefore added to net benefit concept. The third correction is that we do not include gross investments in the benefit concept. Instead, net benefit includes the benefits derived from the stock of public assets. These have to be estimated since there is no observable flow. In most GA studies, this latter correction is not included.

For the base year $t$, the net benefits per cohort $k, N B_{t, k}$ are calculated by assigning the benefits and burdens of the government to the representative individuals of each age group. Using micro data, we assign benefits and burdens to cohorts for all transfer schemes, various benefits in kind, and most taxes. ${ }^{5}$ Approximately $60 \%$ of public expenditures can be assigned to age groups. The remaining $40 \%$ of public spending cannot be assigned to generations as they are pure public goods. These non age-related expenditures (e.g. military expenditures, infrastructure) are distributed evenly over all individuals.

\footnotetext{
2 A detailed description of Gamma can be found in Draper and Armstrong (2007).

3 See Ter Rele (1998) for a more detailed discussion of this concept.

4 Also seigniorage is subtracted from the budget surplus since, like with taxes, they form a cost for private agents for the use of money.

5 We implicitly assume that the representative individual is partly employed, unemployed and disabled. All kinds of taxes and expenditures are assigned to this representative agent per cohort.
} 
For future years, we follow the convention in GA (see European Commission 2009a) by assuming that age-related expenditures are indexed to the wage rate, other expenditures are indexed to gdp and average tax rates are held constant. ${ }^{6}$ In combination with a projection for the demographic change, a time path for the primary surplus $P S_{t+s}$ follows.

\subsection{General Equilibrium}

The Dutch GA are embedded in the overlapping generations model Gamma. The model describes a small open economy that is calibrated for the Netherlands. The prices of tradable goods and the interest rate are determined on world markets. The model distinguishes five sectors: households, firms, the government, a pension fund and the foreign sector.

Every generation is represented by one representative individual. This strong assumption implies that we are able to investigate the intergenerational distribution of net benefits, but not the intragenerational distribution. An individual chooses consumption of goods and leisure by maximizing lifetime utility, subject to the lifetime budget constraint. The death rate increases with age. Households insure against the uncertain lifetime income by buying annuities (Yaari 1965). The consumption profile is hump shaped and based on estimates of Alessie and de Ree (2009). This hump shaped profile can be explained by the household size changes over the life cycle. ${ }^{7}$ Labour supply depends on net wages and net pension accrual. ${ }^{8}$ The net wage is determined by the gross wage minus taxes and pension premiums.

The representative firm uses labour and capital to produce a homogeneous tradable good. The demand for inputs is derived from maximizing the value of the firm. Since investment is subject to adjustment costs, the capital stock responds with delay to changes in employment.

The government accounts are specified in detail due to the inclusion of GA. Government revenues include taxes on labour income, pensions, capital income and consumption. Public expenditures consist of consumption, several transfer schemes, social insurance schemes, education, health care spending and interest. Age profiles are specified for transfers in cash and in kind, including the public PAYG pensions.

Supplementary occupational pensions are provided by pension funds. These are based on a funded system. Pension premiums are compulsory for individual workers and tax deductible. Pension benefits are taxed upon realisation and indexed to the average wage earned over the working life. The replacement ratio depends on the labour history of an individual. Pension rights and benefits are indexed to a combination of

\footnotetext{
6 Deviations from this basic approach are discussed in Sect. 3.1.

7 An annuity market imperfection can account for a hump-shaped pattern of consumption, too (Heijdra and Mierau 2011). However, the estimates of Alessie e.a. point at household composition as the main explanation.

8 The wage effect in Gamma is in line with the empirical evidence, surveyed by Evers et al. (2008). Lumsdaine and Mitchell (1999) conclude in their survey article on early retirement that the wealth effect on labour supply is small relative to the wage effect. The estimates in Blundell and MaCurdy (1999) also point to small wealth effects on labour supply.
} 


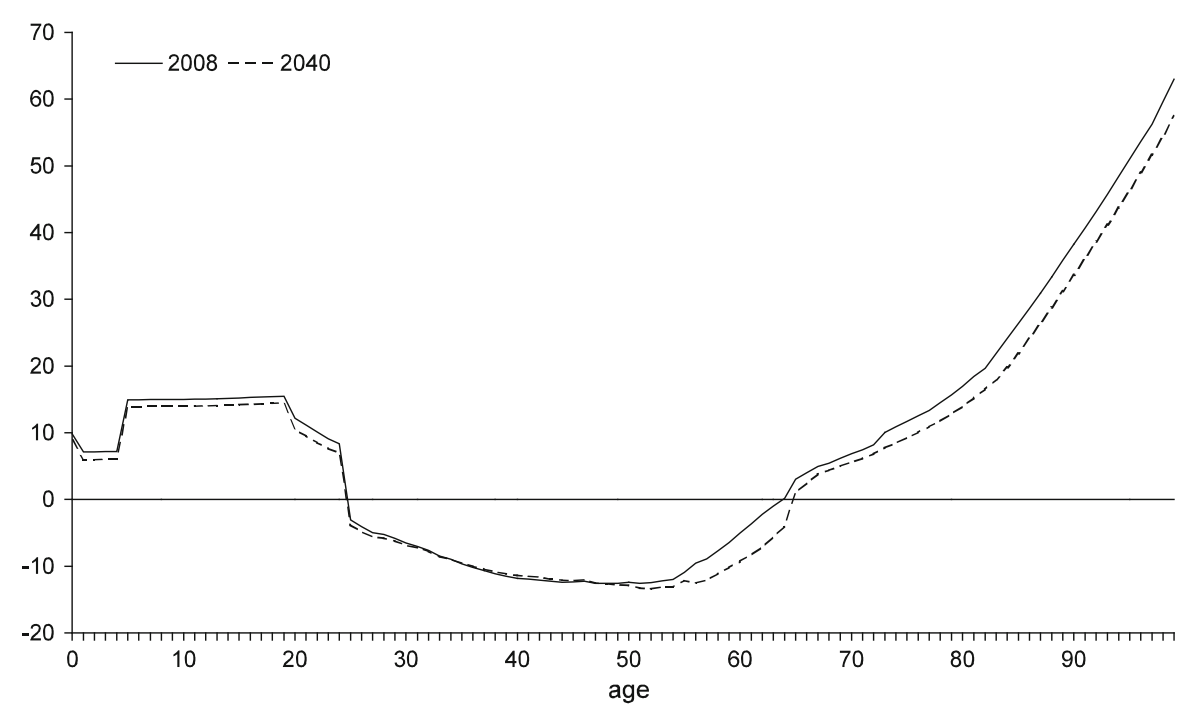

Fig. 1 Age profile of total net benefits from the government in 2008 and 2040 (1,000 euro)

wages and prices. The assets of the pension fund should cover the projected obligations in each year. In case of an initial deficit, the pension fund temporarily raises the premium rate and restricts indexation.

In the small open economy, excess supply of goods can be exported at the given world market price. Similarly, a savings surplus is invested on the world capital market at a fixed interest rate.

The model is calibrated on Dutch national accounts of 2008. The demographic projections are provided by Statistics Netherlands. The calibration is fully discussed in Draper et al. (2010).

\section{Long-term Fiscal Projections for the Netherlands}

Generational accounts have been widely used to assess the long-term developments in public finances. This section offers such a projection in light of the ageing of the Dutch society. Moreover, we explain the assumptions made in these calculations with respect to exogenous trends and policy variables. We also compute the sustainability gap and offer a sensitivity analysis to a number of assumptions.

\subsection{Long-term Projections}

We use Dutch data for 2008 on the distribution of taxes and benefits in cash and in kind to compute the net benefit profile from government. Figure 1 presents the net benefit profile $N B_{2008, k}$ for current generations $k \leq 2008$. We see that, on average, the young and elderly benefit from the government. The young benefit primarily from education expenditures. The old benefit mainly from public pensions and public health care. The middle-aged groups are net contributors to government and face a net tax burden. The number of workers in this middle-aged group relative to the number of retirees above 65 is important for the government budget. Indeed, if the share of elderly increases 
relative to the share of middle-aged workers, aggregate net benefit will rise and the government will run into a deficit.

In making future projections for public expenditures, we distinguish two types of expenditures. We first consider expenditure items of which the benefits can be directly attributed to age groups on the basis of micro data, such as education, social security and health care. We assume that these age-specific expenditures are indexed to wages (The only exception is health care, to which we turn below). This implies that future cohorts of a given age receive the same benefits as a fraction of their income as the current population. Age-related public spending will rise if older cohorts grow in size relatively to younger cohorts. ${ }^{9}$

Second, for other expenditure items, such as defence and general government, we assume that the benefits in each year accrue equally to all individuals. These expenditures are indexed to gdp. The gdp growth depends not only on productivity, but also on employment and investment. Future trends in employment are derived from Euwals and Folmer (2009) who make projections for future developments in Dutch labour market participation. ${ }^{10}$ They find that female participation will rise due to cohort effects, as younger cohorts feature a higher incidence of work than older cohorts. The participation of men is expected to increase due to reforms in Dutch pension schemes, which leads to extended working lives. On average, participation increases from $75 \%$ in 2007 to $78 \%$ in 2040 .

On the revenue side, average tax rates are held constant. Accordingly, aggregate tax receipts will change only via changes in the tax base. With respect to income taxes, the base will expand relative to gdp if a growing number of elderly start to receive taxable pension benefits. With respect to consumption taxes, we assume that private consumption is determined by consumption smoothing, whereby young people save to finance consumption at old age (Alessie and de Ree 2009). Accordingly, ageing implies a rise in consumption relative to gdp so that consumption tax revenue will increase.

An exception is health care costs. In particular, health care expenditures in the Netherlands can be divided into cure and care. Cure involves expenditures on doctors, medicines and hospitals, which are financed by private insurance companies that collect compulsory insurance premiums. Care involves primarily long-term care for elderly and handicapped. In the Netherlands, the lion's share of long-term care is financed collectively via taxation. Figure 2 shows the age profile of cure and care spending in 2008 (Poos et al. 2008). We see that expenditures for cure rise from 1,500 euro for someone younger than 65 to 4,500 euro for someone older than 65 . The age profile for care is steeper. A 67-year old receives 1,000 euro, an 83-year old more than 10,000 euro and a 92-year old more than 30,000 euro. In making future projections, we partly index the health care spending profile to life expectancy. The idea is that, if people grow older, this will not only add years in bad health but also extend the number of years in good health. The relation between health costs and life expectancy is still highly debated; see e.g. the discussion in European Commission (2009a).

\footnotetext{
9 For the level of public spending in percent of gdp, the level of age-specific public benefits in percent of private income and the effective tax rates, we start from levels in 2015 as predicted by CPB (2010).

10 This projection is reproduced on the base path, labour supply is endogenous in policy scenarios.
} 


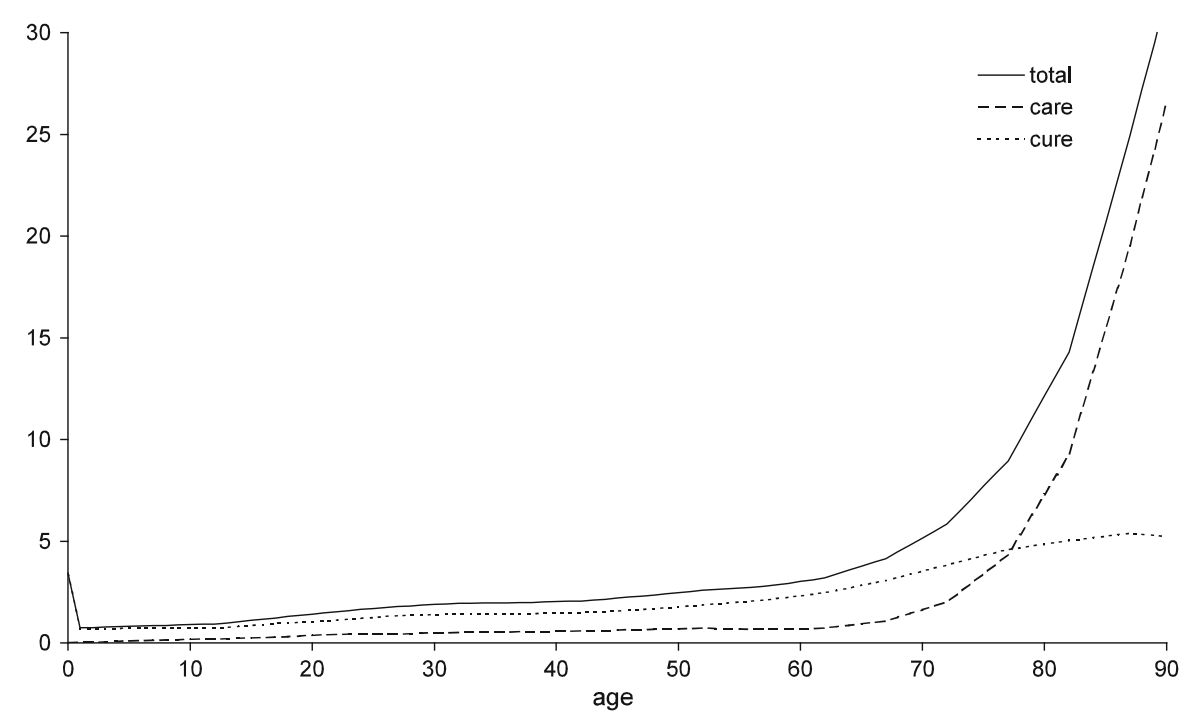

Fig. 2 Age profile health expenditures per person in 2008 (1,000 euro)

In line with the EC, we model an indexation of 50\%, implying that an increase in life expectancy by 2 years adds one year in good health and one year in bad health. Thus, an 83-year old person will receive health benefits that currently apply to an 82-year old person.

As in most industrialized countries, the demographic structure in the Netherlands will change in the coming decades. This is due to a combination of low fertility rates and increasing life expectancy. Indeed, life expectancy at birth will increase by 41/2 years, from just over 80 in 2008 to almost 85 in 2060 (Poelman and van Duin 2010). Fertility is assumed to stabilize at $13 / 4$ child per woman. Figure 3 shows how these developments will change the demographic structure in the Netherlands between 2008 and 2040. ${ }^{11}$ It will imply that the elderly dependency ratio will rise from $25 \%$ in 2008 to over $50 \%$ in $2040 .{ }^{12}$ After 2060 we assume constant mortality rates, fertility rates and net immigration rates. This results in a stable demographic structure with a dependency ratio of $46.5 \%$ in the long run.

In making long-term projections for public spending and taxes, we need to make a number of other assumptions about economic developments. First, we assume that productivity grows by $1.7 \%$ annually. ${ }^{13}$ Second, the real rate of return on savings and debt is set equal to $3 \% .{ }^{14}$ By applying a uniform rate of return (and discount rate) we

\footnotetext{
11 In contrast to the Gamma model, we distinguish males and females in the underlying demographic model.

12 The old age dependency ratio is defined as the ratio of the number of people aged 65 and older to the number of people between 20 and 64 .

13 The economic crisis of 2009 has a permanent impact on the level of gdp. Following CPB (2010), we assume that it has no effect on the rate of growth.

14 We also make assumptions with respect to the behaviour of pension funds (i.e. pension premiums, indexation rules). For details, see Van der Horst et al. (2010).
} 


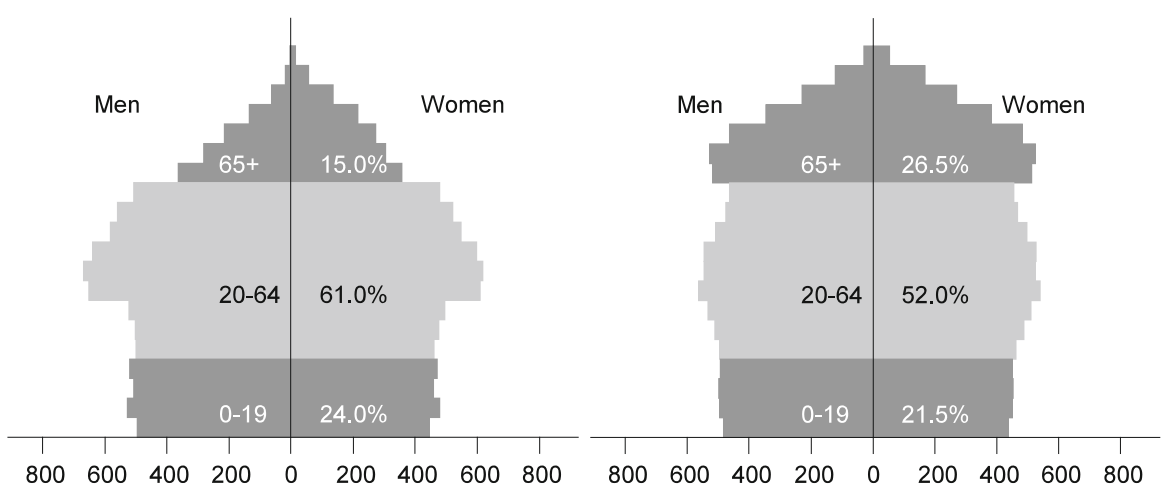

Fig. 3 Demographic distribution 2008 (left) and 2040 (right). The percentages in the figure point to shares of particular cohorts (men and women) in the total population

Table 1 Government expenditures and revenue, 2010-2060, in \% of gdp

\begin{tabular}{lrrrrr}
\hline & 2011 & 2015 & 2020 & 2040 & 2060 \\
\hline Expenditure & & & & & \\
$\quad$ Total expenditures & 50.3 & 49.4 & 50.1 & 57.7 & 59.6 \\
$\quad$ Public pensions & 4.9 & 5.4 & 6.0 & 8.5 & 7.9 \\
$\quad$ Health care & 9.8 & 10.3 & 10.8 & 14.3 & 14.2 \\
$\quad$ Debt services & 2.6 & 3.1 & 2.9 & 4.4 & 7.3 \\
Revenue & & & & & \\
$\quad$ Total revenue & 44.7 & 46.6 & 47.4 & 48.8 & 48.3 \\
$\quad$ Income taxes and social security & & & & & \\
$\quad$ contributions & 22.1 & 23.0 & 23.3 & 24.7 & 24.8 \\
$\quad$ Indirect taxes & 13.3 & 13.3 & 13.8 & 15.4 & 15.2 \\
$\quad$ Natural gas revenue & 1.5 & 1.6 & 1.4 & 0.1 & 0.0 \\
EMU surplus & -5.6 & -2.8 & -2.7 & -8.9 & -11.3 \\
Primary surplus & -3.0 & 0.3 & 0.2 & -4.5 & -4.0 \\
EMU debt & 69 & 74 & 75 & 132 & 217 \\
\hline
\end{tabular}

implicitly assume that all cash flows in the model are subject to the same risk. This can be motivated by the fact that in the long run all relevant cash flows in the model are linked to gdp. ${ }^{15}$ This discount rate is used also to compute the net present value of future public deficits.

The resulting long-term projections for public expenditures and taxes in the Netherlands are presented in Table 1 . We see that public expenditures will rise sharply in light of ageing, especially expenditures on health care and public pensions. The total cost of health care rises from 10\% of gdp in 2011 to more than $14 \%$ in 2040. Public pensions in the first pillar PAYG scheme increase from 5\% in 2011 to $8.5 \%$ in 2040. Most other public expenditures remain stable in terms of gdp.

$\overline{15}$ Bezoni et al. (2007) show that wages, dividends and returns on non-human assets are strongly correlated in the long run. 
We see that tax-to-gdp ratios rise in light of ageing. Indeed, employment falls due to ageing which limits gdp-growth. The reduction in tax payments by workers is, however, partly compensated by taxes on pension income. Accordingly, tax ratios tend to increase. Moreover, due to dissaving, the level of consumption will rise as a share of gdp. This increases the revenue from indirect taxes. Overall, Table 1 shows that tax revenue rises by $4.7 \%$ of gdp. This rise in tax revenue is partly offset, however, by a decline in revenue from natural gas. This generates an annual revenue of $1.5 \%$ of gdp in 2011. In 2060, this will decline to zero due to exhaustion of the resource stock.

As the rise in public expenditures is sharper than the increase in revenues, we see that the budget deficit is expected to rise during the coming decades. Accordingly, public debt will increase. This will raise interest expenditures and cause a gradual explosion of the deficit. Indeed, the deficit will exceed $10 \%$ of gdp in 2060; public debt will exceed $200 \%$ of gdp in 2060 .

\subsection{Assessing the Sustainability Gap}

To assess the long-term sustainability of public finances, we start with the accumulation of public debt $D$ :

$$
D_{t}=(1+r) D_{t-1}-P S_{t}
$$

where we take debt net of financial assets owned by the government. Solving Eq. (2) recursively for government debt in starting year $t=0$, leads to government's intertemporal budget constraint (see Auerbach et al. 1991):

$$
S_{0}=\underbrace{D_{0}}_{\text {Base year debt }}-\underbrace{\sum_{t=0}^{\infty} \frac{P S_{t}}{(1+r)^{t}}}_{\text {Implicit future wealth }} \leq 0
$$

which defines total government's debt $\left(S_{0}\right)$ as the sum of base year debt $\left(D_{0}\right)$ and the implicit debt related to future primary deficits. The implicit debt is defined as the net discounted value of all future primary deficits. The intertemporal budget constraint (3) dictates that total debt $\left(S_{0}\right)$ smaller or equal to zero, i.e. that the government's future primary surpluses have to cover the initial debt.

Total debt can be expressed as a percentage of gdp:

$$
s_{0}=d_{0}-\sum_{t=0}^{\infty} p s_{t}\left(\frac{1+g^{y}}{1+r}\right)^{t} \leq 0
$$

where $g^{y}$ is the growth rate of gdp. ${ }^{16}$ Lower case variables measure variables in percentages of gdp. Both the interest rate and growth rate are assumed to be constant. Variable $s_{0}$ measures the unpaid bill in terms of total public debt as a percentage of

16 For expositional reasons, we consider constant growth. In Gamma, time-varying growth is used instead. 
gdp. In 2015 , the initial debt share $\left(d_{0}\right)$ is projected at $74 \%$ of gdp. Using the estimates for the future development of primary surpluses from the previous subsection, we find that the implicit debt associated with future deficits is $313 \%$ of gdp. Together, the total debt in current government policy $\left(s_{0}\right)$ is thus equal to $387 \%$. More than three-quarter of this is due to future liabilities.

The unpaid bill $\left(s_{0}\right)$ can be expressed as an annuity. If the government improves its primary surplus by $h^{*}$ from now onwards, meeting the intertemporal budget constraint requires:

$$
d_{0}-\sum_{t=0}^{\infty}\left(p s_{t}+h^{*}\right)\left(\frac{1+g^{y}}{1+r}\right)^{t}=0 \Rightarrow h^{*} \approx\left(r-g^{y}\right) s_{0}
$$

$h^{*}$ is the sustainability gap in percentages of gdp. The term $\left(r-g^{y}\right)$ translates the total debt, $s_{0}$, into a necessary, yearly improvement in the primary surplus, $h^{*}$. Both the discount rate $(r)$ and the growth rate of $g d p\left(g^{y}\right)$ are taken into account because $h^{*}$ is expressed in percentages of gdp. ${ }^{17}$ As we assume that $r=3 \%$ and $g^{y} \approx 1.7 \%$ (given very limited employment growth), we find that $h^{*}=4.5 \%$ of gdp in 2015 .

\subsection{Sensitivity Analysis}

The sustainability gap of $4.5 \%$ of gdp depends on several assumptions about trends in exogenous variables, such as the productivity growth rate, the interest rate, demographic developments, and participation. This section offers a sensitivity analysis to show how the sustainability gap changes under alternative assumptions. Table 2 summarizes the results.

In the baseline, health care expenditures per person increase with wages. However, recent developments suggest that these expenditures may rise more sharply in the future. First, medical technology is advancing rapidly. While this may sometimes cause savings in health care spending, most technological innovations lead to quality improvements that render health care more expensive (European Commission 2009a). Second, labour productivity growth in health care tends to lag behind the productivity growth in the market sector. At the same time, wages in the health care sector rise with market wages. This phenomenon, known as the Baumol disease, implies that health care becomes more expensive over time: the same services are provided at a higher price (Baumol and Bowen 1966). Finally, the income elasticity of health care demand is believed to exceed one. With rising welfare, the share of health care spending in the total budget may thus expand.

If these three issues turn out to be important in the future, health care expenditures may rise faster than we assume in our baseline. In Table 2, we show the effects when

17 This sustainability gap is identically defined as the S2-indicator of the European Commission (2009). Their estimate of the sustainability gap is higher, $7 \%$ of gdp, for two main reasons. Firstly, their projection for the life expectancy is higher. Secondly, our estimate includes a sizable improvement of the budget between 2010 and 2015, as projected by CPB (2010). This improvement is due to a different methodology of projecting public finances in this period, assuming unchanged policy. Among others, this implies very limited growth of public expenditures. 
Table 2 Sensitivity for alternative assumptions (in deviation of the unsustainable base path)

\begin{tabular}{|c|c|c|c|c|c|c|c|}
\hline & $\begin{array}{l}\text { Higher } \\
\text { growth } \\
\text { health } \\
\text { care }\end{array}$ & $\begin{array}{l}\text { Constant } \\
\text { health } \\
\text { profiles }\end{array}$ & $\begin{array}{l}\text { Longer } \\
\text { life } \\
\text { expec- } \\
\text { tancy }\end{array}$ & $\begin{array}{l}\text { Higher } \\
\text { fertility }\end{array}$ & $\begin{array}{l}\text { Higher } \\
\text { participa- } \\
\text { tion }\end{array}$ & $\begin{array}{l}\text { Lower } \\
\text { produc- } \\
\text { tivity }\end{array}$ & $\begin{array}{l}\text { Higher } \\
\text { expected } \\
\text { interest } \\
\text { rate }\end{array}$ \\
\hline \multicolumn{8}{|c|}{ Public finance 2040 (change $\%$ of gdp) } \\
\hline Government revenues & 0.0 & 0.0 & 0.0 & 0.0 & -0.1 & 0.6 & 0.8 \\
\hline Of which income taxes ${ }^{a}$ & 0.0 & 0.0 & -0.1 & 0.0 & 0.0 & 0.4 & 0.5 \\
\hline Of which indirect taxes & 0.0 & 0.0 & 0.1 & 0.0 & 0.0 & 0.1 & 0.3 \\
\hline Government expenditures ${ }^{b}$ & 4.1 & 1.2 & 0.5 & 0.4 & -0.3 & -0.1 & 0.0 \\
\hline Of which public pensions & 0.0 & 0.0 & 0.3 & -0.1 & -0.1 & 0.0 & 0.0 \\
\hline Of which health care & 4.1 & 1.2 & 0.2 & 0.0 & -0.1 & 0.0 & 0.0 \\
\hline Interest payments & 1.5 & 0.6 & 0.1 & 0.3 & -0.3 & 0.0 & -0.7 \\
\hline EMU balance & -5.6 & -1.8 & -0.5 & -0.7 & 0.6 & 0.7 & 1.4 \\
\hline EMU debt & 48.1 & 17.4 & 3.8 & 8.0 & -8.4 & 0.0 & -20.6 \\
\hline \multicolumn{8}{|c|}{ Sustainability gap 2015 (change \% of gdp) } \\
\hline Change in 2015 & 3.4 & 1.5 & 0.9 & 0.1 & -0.3 & -0.6 & -0.8 \\
\hline \multicolumn{8}{|c|}{ Economic effects 2040 (percentage changes) } \\
\hline Gross domestic product & 0.0 & 0.0 & 0.1 & 1.3 & 1.0 & -13.5 & 0.1 \\
\hline Employment $^{\mathrm{c}}$ & 0.0 & 0.0 & 0.0 & 1.9 & 1.0 & 0.0 & 0.0 \\
\hline Private consumption & 0.0 & 0.0 & 0.9 & 1.1 & 0.6 & -11.5 & 2.1 \\
\hline
\end{tabular}

a On labour income and transfers

${ }^{\mathrm{b}}$ Exclusive interests

${ }^{\mathrm{c}}$ Full time equivalents

the annual growth rate of health care expenditures is $1 \%$ larger than on the baseline between 2015 and 2040. This corresponds to the development during the last decade. At the same time, we keep insurance premiums unchanged. As a result, the sustainability gap gets larger. We see that public spending on health care will have increased by $4.1 \%$ of gdp in 2040 under this alternative scenario. The sustainability gap would become $7.9 \%$ instead of $4.5 \%$ and is thus $3.4 \%$ larger.

In our baseline, we assume that the age profile of health care spending is for $50 \%$ indexed to life expectancy. This captures the idea that people not only live longer but also longer in good health. In the second column of Table 2, we assume that the age profile does not change, even if life expectancy increases. We see that this results in a $1.5 \%$ of gdp higher sustainability gap.

The projected life expectancy at birth in the baseline is $4 \frac{1}{2} 2$ years longer in 2050 compared to 2010. Predictions of life expectancy are highly uncertain, however (Alho et al. 2008). In the third column of Table 2, we look at the implications if life expectancy would rise by another 2 years until 2050. We see that this will increase the sustainability gap by $0.9 \%$. Especially expenditures on first pillar pensions and health care will increase relative to gdp.

We assume that women give birth to 1.7 children in the Netherlands, the same figure as we observe today. In the fourth column of Table 2, we show what happens to 
public finances if the fertility rate would increase to 1.9. We see that this deteriorates the sustainability gap by $0.1 \%$. The reason is that the Dutch government currently has a positive net wealth. Indeed, the Dutch government owns a substantial stock of public capital, natural resources and financial assets which together exceed the current level of public debt. This is also the case after the deduction of the future net claims on it by the current generations. With a higher fertility rate therefore, new borns will share in this positive net wealth. Thus, they will receive more benefits from the government during their life than they pay in terms of taxes. Accordingly, an increase in fertility exacerbates the sustainability problem in the Netherlands. A similar effect on sustainability would result from higher immigration (see Roodenburg et al. 2003). Of course, this crucially depends on the characteristics of an immigrant, like her age (an immigrant of age 25 has received her education in the home country) and education level (highly educated immigrants are more favourable for the government budget on average).

In the baseline projection, labour market participation increases from $75 \%$ in 2007 to $78 \%$ in 2040. In Table 2, we look at the consequences of an additional 1\%-point rise in labour participation (caused by exogenous developments). We see that this would leave public revenue more or less unchanged as a share of gdp. However, government expenditures fall. The reason is that a higher level of employment causes an expansion of gdp, thereby also raising the level of pure public goods. However, age-related public expenditures are indexed to wage rates, not to gdp. As wage rates do not rise, these expenditures fall as a share of gdp. This causes an improvement in the sustainability gap by $0.3 \%$ of gdp.

We assume that labour productivity increases by $1.7 \%$ per year in the baseline. In Table 2, we explore the implications if the growth rate would be $1.2 \%$. We see that this improves the sustainability gap by $0.6 \%$. This may seem counter-intuitive. Recall, however, that all public expenditures are indexed to either wages or gdp. Hence, lower growth leads to an immediate proportional reduction in public expenditures. However, government income declines less than gdp for three reasons. First, the return on pension wealth depends on the interest rate, which is unchanged. However, pension benefits are indexed to wages and thus decline. This reduces pension premiums, which are tax exempt. Accordingly, the average tax rate rises a bit. Second, households increase their savings because they will be poorer after retirement. Indeed, consumption smoothing motives imply higher savings. This raises tax revenues on capital income. Third, income from natural gas does not depend on the production development. Overall, lower productivity thus improves the sustainability of public finances.

We assume a $3 \%$ real interest rate in the baseline. The interest rate is, however, highly uncertain. We analyse in Table 2 an alternative scenario with a $0.5 \%$ higher interest rate. In particular, we first re-calibrate the model using a higher interest rate. Hence, observed variables in 2008 are reproduced with this higher interest rate. In that sense, the higher interest rate is anticipated by private agents. We then compute how this affects the outcomes. We observe from Table 2 that sustainability improves by $0.8 \%$ of gdp if the interest rate is higher. The reason is that pension funds obtain a higher return on their assets. Accordingly, they reduce their pension premiums as this suffices to meet their obligations. Lower pension premiums broaden the tax base and 
increase revenues from income taxes. Moreover, a higher rate of return to capital also raises consumption in the long run, so that indirect tax revenue rises as well.

In sum, the sensitivity analysis reveals that sustainability remains an issue even for alternative assumptions in key dimension. Of course, the size of the alternatives is debatable, but given the near-linearity of the model, the reader can easily double both the responses and the effects. Only in very exceptional cases, like a very limited growth in health care expenditures, a serious reduction in life expectancy or a doubling of the interest rate would a negative gap result.

\section{The Impact of Policy Reform}

The sustainability of public finances can be improved by policy reform, now or in the future. This section assesses different economic, budgetary and intergenerational effects of policy reforms. We consider three types of reform: cutting government expenditures, increasing taxes, and public pension reforms. For each of these measures, we investigate two issues. First, by how much does the reform reduce the sustainability gap? Second, how does the reform affect the net benefit from the government for different generations? The presentation of net benefits per cohort is explained in Sect. 4.1. The policy reforms follow in the subsequent sections.

\subsection{Policy Reforms and Net Benefits}

To assess the impact of a policy reform on the intergenerational distribution, we calculate the annual change in lifetime net benefits for each cohort $\Delta L N B_{t, k}^{c a}$. First, we define the present value of net benefits over the remaining lifetimes $L N B$. For the current generations the lifetime net benefits per capita are:

$$
L N B_{t, k}=\sum_{s=t}^{k+T} N B_{s, k} \frac{A_{s, k}}{A_{t, k}} \frac{1}{(1+r)^{s-t}}, \quad k \leq t
$$

where $A_{s, k}$ denotes the number of people of cohort born in $k$ who are alive in year $s$. Equation (6) assumes a discount rate $r, t$ denotes the base year and $T$ denotes the maximum age (99). For future generations, we calculate the lifetime net benefits at birth as: ${ }^{18}$

$$
L N B_{k, k}=\frac{1}{(1+g)^{k-t}} \sum_{s=k}^{k+T} N B_{s, k} \frac{A_{s, k}}{A_{k, k}} \frac{1}{(1+r)^{s-k}}, \quad k>t
$$

The first term in this equation corrects for the fact that each newborn cohort starts with an earnings potential that is $g$ percent larger than that of the previous cohort, due to exogenous technological progress. Lifetime benefits are scaled for the exogenous

\footnotetext{
18 For expositional reasons, a constant $\mathrm{g}$ is assumed in the equations. The calculations in Gamma are performed with the time-varying growth rates.
} 
growth of labour productivity (at rate $g$ ) to make the results better comparable between the generations.

To show the impact of policy on the net benefits, we compute the change in lifetime net benefits $\triangle L N B_{x, k}$. We express the impact of the reforms as a constant growthadjusted annuity, which gives an indication for the average annual change in net lifetime benefit $\triangle L N B_{x, k}^{c a}$ :

$$
\Delta L N B_{x, k}^{c a}=\frac{\Delta L N B_{x, k}}{\sum_{s=x}^{k+T} \frac{A_{s, k}}{A_{x, k}}\left(\frac{1+g}{1+r}\right)^{s-x}}, \quad x=\max (t, k)
$$

Hence, if net benefit falls by $y$ euro for generation $k$, this means that generation $k$ suffers a loss in net benefit of $y$ euros per year during the rest of its life (expressed in growth-adjusted euros of the base year 2010).

Policy reforms are implemented in 2011, unless stated otherwise. The effects are presented relative to the base path. ${ }^{19}$ The improvement of the sustainability gap is evaluated in the year 2015. The results for the macroeconomic aggregates and other public finance indicators are reported for the year 2040.

\subsection{Lower Public Expenditures}

One way to consolidate public finances is to reduce government expenditures. We simulate a cutback in expenditures on material consumption, public health care (labelled as cure) and long-term care (labelled as care). The measure involves a permanent reduction in expenditure in 2011 that amounts to $1 \%$ of gdp. Since these expenditures have no behavioural feedback effects in the model, the reforms leave private consumption, labour supply and gdp unaffected.

The first column of Table 3 presents the effects of reducing material government consumption by $1 \%$ of gdp. Sustainability improves by $1 \%$ of gdp in 2015 . Due to lower interest payments, the EMU balance improves by $1.9 \%$ of gdp in $2040 .{ }^{20}$ The EMU debt is reduced by $28 \%$ of gdp. The consequences for current and future generations are presented in Fig. 4, where the generations are identified by their year of birth on the x-axis. The solid line shows that all generations lose 345 euro per year of net benefit from government.

The second and third column in Table 3 show the effects of cutting expenditures on public cure and care by $1 \%$ of gdp, respectively. Since the health care insurance premiums are not changed, this saves net public expenditures. With the ageing of the population, the initial reduction in expenditures yields extra savings over time, because the number of elderly with relatively high health care costs per person increases (see

\footnotetext{
19 This is the base path without the closure of the intertemporal budget of the government.

20 The items in the table that are expressed in terms of gdp in market prices can deviate from the initial $1 \%$-shock. The reason is that government consumption on the base path is linked to gdp in factor costs. The latter grows less than gdp in market prices because consumption increases more than gdp following the ageing of the population. The accompanying increase in indirect taxes explains the faster growth of gdp in market prices.
} 
Table 3 Effects of expenditures cuts by $1 \%$ of gdp in 2011 on public finances, net benefits and the economy

\begin{tabular}{|c|c|c|c|}
\hline & $\begin{array}{l}\text { Government } \\
\text { consumption }\end{array}$ & Cure-expenditures & Care-expenditures \\
\hline \multicolumn{4}{|l|}{ Public finance 2040 (change \% of gdp) } \\
\hline Government revenues & 0.0 & 0.0 & 0.0 \\
\hline $\begin{array}{l}\text { Of which taxes on labour } \\
\text { income and transfers }\end{array}$ & 0.0 & 0.0 & 0.0 \\
\hline Of which indirect taxes & 0.0 & 0.0 & 0.0 \\
\hline $\begin{array}{l}\text { Government expenditures } \\
\text { (excl. interests) }\end{array}$ & -0.9 & -1.3 & -1.7 \\
\hline Of which public pensions & 0.0 & 0.0 & 0.0 \\
\hline Of which health care & 0.0 & -1.3 & -1.7 \\
\hline Interest payments & -1.0 & -1.2 & -1.3 \\
\hline EMU balance & 1.9 & 2.5 & 3.0 \\
\hline EMU debt & -28.3 & -36.0 & -39.5 \\
\hline \multicolumn{4}{|l|}{ Sustainability gap 2015 (change $\%$ of gdp) } \\
\hline Change in 2015 & -1.0 & -1.3 & -1.7 \\
\hline \multicolumn{4}{|c|}{ Economic effects 2040 (percentage changes) } \\
\hline Gross domestic product & 0.0 & 0.0 & 0.0 \\
\hline Employment (full time equivalents) & 0.0 & 0.0 & 0.0 \\
\hline Private consumption & 0.0 & 0.0 & 0.0 \\
\hline
\end{tabular}

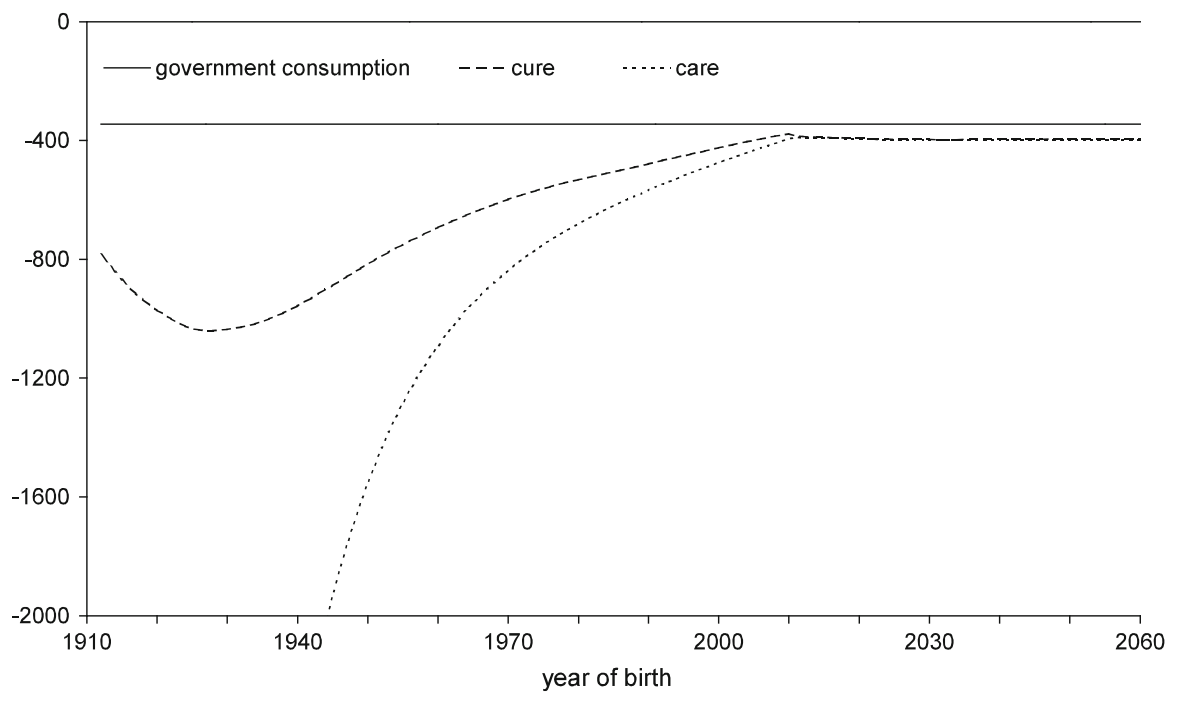

Fig. 4 Effect of expenditures cuts on net benefits of generations (euros per year) 
Fig. 2). The improved primary balance and the lower interest payments in 2040 result in a lower EMU deficit and lower debt due to both reforms.

The rising age-profiles of health care costs are also reflected in the generational pattern of the reduction in net benefits in Fig. 4. The cut in health care spending harms in particular the currently old generations. With the cure-reform, generations born around 1930 face the largest annual reduction of around 1,000 euro during the rest of their lives. ${ }^{21}$ In the care-reform, the current generations older than 90 years lose more than 8,500 euro per year. In both variants, the reduction in net benefit is around 400 euro per year for future generations. ${ }^{22}$

\subsection{An Increase in Taxes}

Higher taxes also contribute to a reduction of the sustainability gap. We consider an increase in two tax rates: of the income $\operatorname{tax}^{23}$ and of the consumption tax. The rise in each tax rate is scaled to yield $1 \%$ of gdp in extra tax revenues in 2011, i.e. before behavioural responses are taken into account.

The first column in Table 4 gives the outcomes for the increase in income taxes. The total effect on income taxes exceeds the initial impulse by $0.5 \%$ of gdp. This is due to the fact that the income tax reduces labour supply and thus gdp. Tax revenues decline less, because pension income is indexed to the wage rate, not to gdp. Similar reasoning implies an increase in the expenditure to gdp ratios of $0.4 \%$ of gdp. Private consumption and thus indirect tax revenues fall due to the reduction of disposable income. On balance the sustainability gap improves by $0.9 \%$ of gdp, slightly less than the impulse of $1.0 \%$.

The solid line in Fig. 5 shows the impact on the intergenerational distribution. Generations born before 1950 lose only 150 euro per year. They are already retired and pay a lower tax rate than working generations. The current, working generations are affected the most because they face higher income taxes in the remainder of their life. The maximum loss is 420 euro. The loss for future generations is smaller (300 euro) since they do not pay income taxes during the first 20 years of their lives.

In the second column of Table 4, we show the impact of a higher consumption tax rate. We find that sustainability improves less than $1 \%$ of gdp due to two main effects. First, in response to a reduction in the real wage rate, labour supply, gdp and consumption decline. This leads to a reduction in both tax revenues and public transfers, with a negative impact on balance. Second, indirect taxes increase relative to gdp over time. The stronger growth of the relevant tax base follows the rising fraction of consumption by the elderly. This slightly raises the indirect tax revenue.

\footnotetext{
21 Note that cure costs reach its peak at age 87, see Fig. 2.

22 This relatively small reduction is due to the concentration of health care expenditure at older ages, which are spread over the entire life in calculation of the annual change.

23 To be precise, we increase the tax rate (including social premiums) imposed on labour income, pension income and transfers (i.e. the tax base of box 1). Pension premiums can be deducted from the tax base.
} 
Table 4 Effects of raising taxes by $1 \%$ of gdp in 2011 on public finances, net benefits and the economy

\begin{tabular}{lcc}
\hline & Direct taxes & Indirect taxes \\
\hline Public finance 2040 (change \% of gdp) & & \\
Government revenues & 1.2 & 0.5 \\
Of which taxes on labour income and transfers & 1.5 & -0.2 \\
Of which indirect taxes & -0.3 & 0.7 \\
Government expenditures (excl. interests) & 0.4 & -0.3 \\
Of which public pensions & 0.1 & 0.0 \\
Of which health care & 0.1 & -0.1 \\
Interest payments & -0.7 & -0.7 \\
EMU balance & 1.6 & 1.5 \\
EMU debt & -22.3 & -20.9 \\
Sustainability gap 2015 (change \% of gdp) & & \\
Change in 2015 & -0.9 & -0.8 \\
Economic effects 2040 (percentage changes) & & -0.4 \\
Gross domestic product & -0.6 & -0.4 \\
Employment (full time equivalents) & -0.6 & -2.4 \\
Private consumption & -2.9 & \\
\hline
\end{tabular}

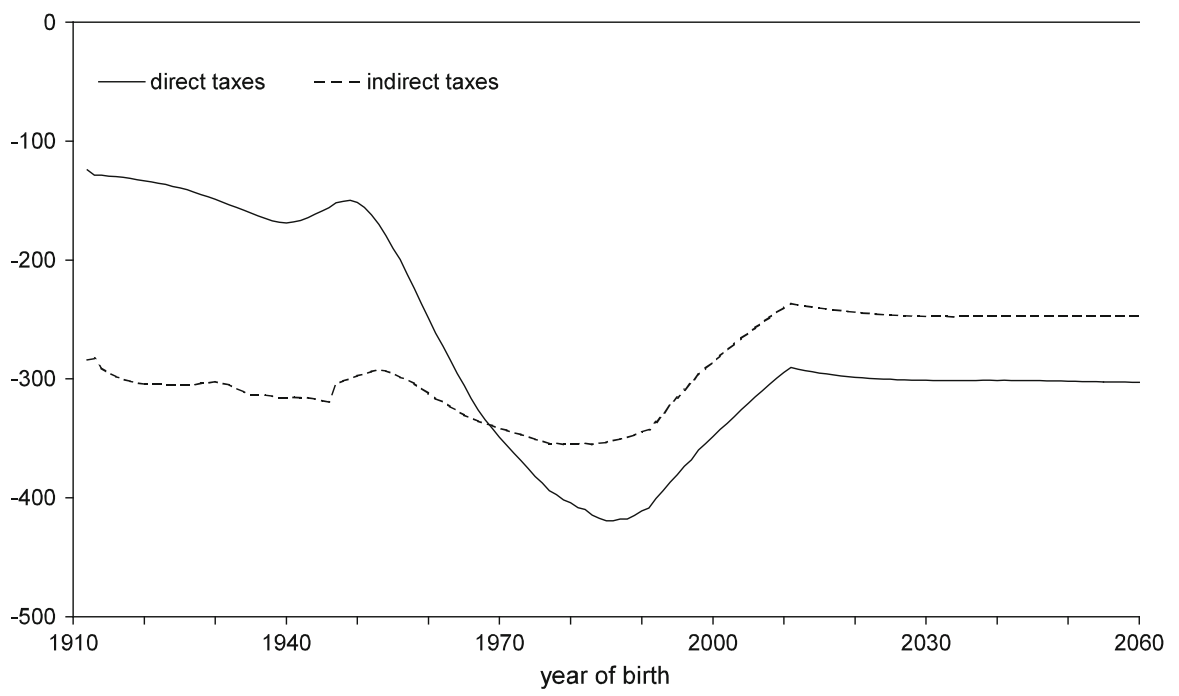

Fig. 5 Effect of raising taxes on net benefits of generations (euros per year)

The reduction in net benefits of current generations is rather stable at 300 euro, since consumption is smoothed over the lifetime (Fig. 5). Future generations contribute less (250 euro) in view of the low consumption early in life. 
Table 5 Effects of public pensions reforms on public finances, net benefits and the economy

retirement age- $67^{\mathrm{a}}$ retirement age- $69^{\mathrm{b}}$ lower indexation $^{\mathrm{c}}$

\begin{tabular}{lrrr}
\hline Public finance 2040 (change \% of gdp) & & & \\
Government revenues & 0.2 & 0.1 & -1.0 \\
Of which taxes on labour income and transfers & 0.3 & 0.3 & -0.5 \\
Of which indirect taxes & -0.1 & -0.2 & -0.5 \\
Government expenditures (excl. interests) & -0.7 & -1.5 & -3.2 \\
Of which public pensions & -0.7 & -1.5 & -3.4 \\
Of which health care & -0.1 & -0.2 & 0.1 \\
Interest payments & -0.5 & -0.6 & -0.6 \\
EMU balance & 1.4 & 2.2 & 2.8 \\
EMU debt & -16.0 & -17.5 & -20.2 \\
Sustainability gap 2015 (change \% of gdp) & & & \\
Change in 2015 & -0.7 & -1.3 & -1.8 \\
Economic effects 2040 (percentage changes) & & & \\
Gross domestic product & 1.0 & 1.8 & 0.0 \\
Employment (full time equivalents) & 1.0 & 2.0 & 0.0 \\
Private consumption & -0.3 & -0.3 & -4.6 \\
\hline
\end{tabular}

a Increase retirement age to the age of 66 years in 2015 and 67 years in 2025

b First scenario plus increase retirement age to the age of 68 years in 2030 and 69 years in 2035

c The indexation of public pensions is exclusive of productivity growth over the period 2011-2040

\subsection{Reforms of Public Pensions}

The third set of reforms involves public pensions. In the first two reforms, we raise the statutory retirement age. In the third reform, we reduce pension benefits by indexing public pensions to prices instead of wages. The results are given in Table 5 and Fig. 6.

According to projections, persons will not only live longer but will also live longer in better health. Many countries have decided to raise, immediately or gradually, the statutory retirement age, while similar plans are proposed in the Netherlands. In the first column of Table 5 the statutory retirement age is increased in two steps: from 65 to 66 in 2015 and subsequently to 67 in 2025. The higher retirement age applies to benefits in the first pillar of public pensions and in the second pillar of mandatory private pensions. The pay-as-you-go public pension is financed by taxes (which are not changed). The pension benefit in the funded private system depends on the average wage and the number of contributing years of the participant. Since less pension rights are accumulated per working year after the pension reform, pension premiums are reduced.

Raising the retirement age improves sustainability by $0.7 \%$ of gdp mainly due to lower public expenditures. Savings on public pensions (starting in 2015) are partially offset by higher unemployment, disability and welfare benefits to persons aged 65 and 66. Improvements in the budget are obtained, however, by three other channels. First, subsidies in the second pillar decline since less pension premiums are deducted from 


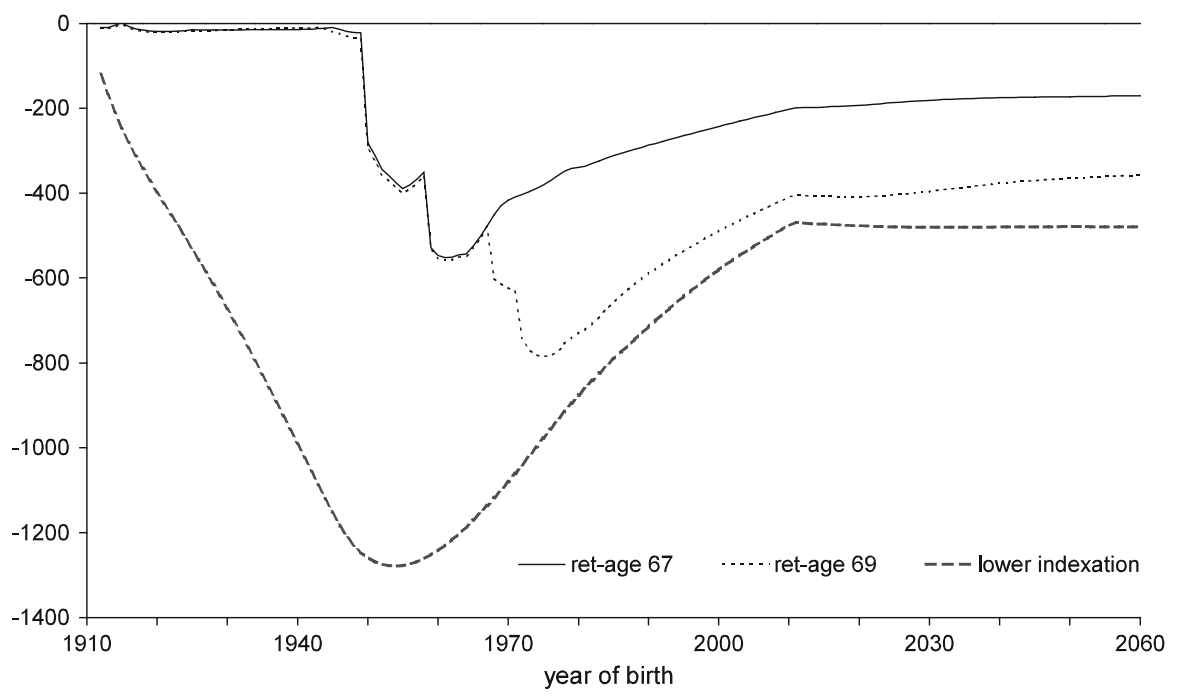

Fig. 6 Effect of public pension reforms on net benefits of generations (euros per year)

the income tax base. Second, the higher pension age increases the level of employment by $1 \%$. This broadens the tax base and raises revenue. Third, pension reform stimulates private savings. As these savings are taxed, this raises tax revenue. As a net effect, the EMU balance and public debt in 2040 improve by $1.4 \%$ and $16.0 \%$ of gdp, respectively.

The stepwise increase in the retirement age leads to an uneven distribution of the ageing costs in Fig. 6. Generations born before 1950 do not suffer since they retire before 2015. Generations born between 1950 and 1959 face a loss of 400 euro per year. Generations born after 1959 suffer the largest decline as they are hit by the second increase. Net benefits recover for younger generations, because they spread out their future losses over more years of life. Lifetime benefits fall by 200 euro per year for future generations.

In the second reform, the retirement age is further increased by one year in 2035 and by one year in 2040. Relative to the first reform, the sustainability gap declines by an extra $0.6 \%$ of gdp. The full impact of raising the retirement age to 69 years emerges after 2040. Generations born before 1968 still receive a pension income not later than at the age of 67 (see Fig. 6). In contrast, generations born after 1968 and after 1972 can only claim pension benefits one and two years later, respectively. The generation born in 1972 is confronted with the largest loss of net benefit by 800 euro per year over the rest of their lives. Future generations lose 400 euro per year.

Some countries, like Italy, plan to curtail the future rise in outlays by limiting the accrual of pension rights related to contributions during the working years. ${ }^{24}$ In our

24 The European Commission (2009b) reports projections of the pension expenditures for all the EU-members. Notwithstanding the rising share of pensioners, expenditures on public pensions in Italy even fall from $14.0 \%$ in 2007 to $13.6 \%$ of gdp in 2060 . However, this comes at the expense of the wellbeing of pensioners. Indeed, the pension benefit to wage ratio decreases from 68 to $47 \%$ in 2060 . 
baseline, public pensions are indexed to the wage rate. In the long run, this wage growth equals the productivity growth $(1.7 \%)$. In an alternative scenario, we explore what happens if public pensions in the Netherlands would be indexed to prices instead of wages, i.e. would not grow in real terms. The last column in Table 5 shows that, lower public pensions do not affect employment and gdp in the model, as we ignore income effects on labour supply. The savings on expenditures on public pensions in 2040 are partly offset by lower tax revenues, especially lower indirect tax revenues due to the strong reduction of consumption. The EMU balance improves by $2.8 \%$ and public debt falls by $20.2 \%$ of gdp in 2040 . The sustainability gap declines by $1.8 \%$ in 2015.

Figure 6 shows that current generations suffer large losses if public pensions are indexed to prices instead of wages. Generations born in the fifties suffer most, up to a maximum of 1,250 euros per year. They receive lower pensions during most of their retirement period. Future generations suffer a smaller annual loss, as their reduction in pension income is spread out over their entire life cycle.

\section{Conclusion}

Future generations are affected by current policies but have no voice. The government will run into huge deficits and debts if current policies remain as they are. The question is not whether these deficits have to be covered, but how, when and by whom. This paper focuses primarily on the latter question, by whom. It also shows that this is closely related to policy design. Health care reforms strongly affect the currently old generations; current workers bear the majority of labour tax and pension reforms; consumption tax reforms are more equally borne by all generations; and delaying reforms passes the bill to future generations.

These policy reforms are investigated with an overlapping generations model for the Netherlands that incorporates generational accounting. This model shows how policy reforms affect the economy through behavioural responses in labour supply, consumption and savings. And it shows who pays for or benefits from the reforms. We pay due attention to the intergenerational distribution of policy reforms, but abstract from heterogeneity within cohorts. This extension to intragenerational distribution is desirable as it matters for policy whether reforms affect the currently poor or the future rich.

Acknowledgements We would like to thank two anonymous referees for their constructive comments.

Open Access This article is distributed under the terms of the Creative Commons Attribution Noncommercial License which permits any noncommercial use, distribution, and reproduction in any medium, provided the original author(s) and source are credited.

\section{References}

Alessie, R., \& de Ree, J. (2009). Explaining the hump in life cycle consumption profiles. De Economist, 157, 107-120. 
Alho, J. M., Jensen, S. E. H., \& Lassila, J. (2008). Uncertain demographics and fiscal sustainability. Cambridge: Cambridge University Press.

Auerbach, A. J., Gokhale, J., \& Kotlikoff, L. J. (1991). Generational accounts: A meaningful alternative to deficit accounting. In D. Bradford (Ed.), Tax policy and the economy 5 (pp. 55-110). Cambridge, MA: MIT Press.

Auerbach, A. J., Kotlikoff, L. J., \& Leibfritz, W. (1999). Generational accounting around the world. Chicago: The University of Chicago Press.

Baumol, W. J., \& Bowen, W. G. (1966). Performing arts: The economic dilemma. New York: The Twentieth Century Fund.

Bezoni, L., Collin-Dufresne, P., \& Goldstein, R. S. (2007). Portfolio choice over the life-cycle when the stock and labor markets are cointegrated. Journal of Finance, 62(5), 2123-2167.

Blundell, R., \& MaCurdy, T. (1999). Labor supply: A review of alternative approaches. In Handbook of labor economics, Vol. 3, North Holland.

Buiter, W. (1995). Do generational accounts reveal the effect of the budget on savings and intergenerational redistribution?, NBER working paper 5087.

CPB. (2010). Economische Verkenning 2011-2015, CPB document 203.

Draper, N., \& Armstrong, A. (2007). GAMMA, a simulation model for ageing, pensions and public finances, CPB document 147, The Hague.

Draper, N., Bettendorf, L., Bonenkamp, J., Nibbelink, A., Rosenbrand, R., \& ter Rele, H. (2010). Calibration of gamma 2010, CPB Memorandum 248.

Draper, N., \& Westerhout, E. (2010). Privatizing pensions: More than an interesting thought? mimeo $\mathrm{CPB}$, The Hague.

Evers, M., de Mooij, R., \& van Vuuren, D. (2008). The wage elasticity of labour supply: A synthesis of empirical estimates. De Economist, 156(1), 25-43.

European Commission. (2009a). The 2009 ageing report: Economic and budgetary projections for the EU-27 member states, European Economy nr 2, Brussels.

European Commission. (2009b). Sustainability report 2009, European Economy nr 9, Brussels.

Euwals, R., \& Folmer, K., (2009). Arbeidsaanbod en gewerkte uren tot 2050, CPB Memorandum 225.

Fehr, H., \& Kotlikoff, L. J. (1996). Generational accounting in general equilibrium. FinanzArchiv, 53(1), $1-27$.

Haveman, R. (1994). Should generational accounts replace public budgets and deficits?. Journal of Economic Perspectives, 8(1), 95-111.

Heijdra, B. J., \& Mierau, J. O. (2011). The individual life cycle and economic growth: An essay on demographic macroeconomics, De Economist, 159. doi:10.1007/s10645-010-9153-2

Kotlikoff, L. J. (2002). Generational policy. In: A. J. Auerbach, M. Feldstein (Eds.), Handbook of public economics (Vol. 4, pp. 1873-1932). Amsterdam, North Holland

Lumsdaine, R., \& Mitchell, O. (1999). New developments in the economic analysis of retirement. In: O. Ashenfelter, D. Card (Eds.), Handbook of labor economics, Vol. 3, Elsevier Science

Poelman, B., \& van Duin, C. (2010). Bevolkingsprognose 2009-2060, Publicatiedatum CBS-website: 12 maart 2010, Den Haag/Heerlen.

Poos, M. J. J. C., Smit, J. M., Groen, J., Kommer, G. J., \& Slobbe, L. C. J. (2008). Kosten van Ziekten in Nederland 2005, RIVM-rapport 270751019.

Roodenburg, H., Euwals, R., ter Rele, H. J. M. (2003) Immigration and the Dutch economy. CPB Special Study 47, The Hague

Ter Rele, H. (1998). Generational accounts for the Netherlands. De Economist, 146, 555-584.

Van der Horst, A., Bettendorf, L., Draper, N., van Ewijk, C., de Mooij, R., \& ter Rele, H. (2010). Vergrijzing verdeeld, CPB special publication 86, The Hague.

Yaari, M. E. (1965). Uncertain lifetime, life insurance, and the theory of the consumer. The Review of Economic Studies, 32(2), 137-150. 